Research article

\title{
The expression and antigenicity of a truncated spike-nucleocapsid fusion protein of severe acute respiratory syndrome-associated coronavirus
}

\author{
Feng $\mathrm{Mu}^{\dagger 1}$, Dongsheng $\mathrm{Niu}^{\dagger 2}$, Jingsong $\mathrm{Mu}^{\dagger 3}$, $\mathrm{Bo} \mathrm{He}^{1}$, Weiguo $\mathrm{Han}^{2}$, \\ Baoxing Fan ${ }^{4}$, Shengyong Huang ${ }^{1}$, Yan Qiu ${ }^{5}$, Bo You ${ }^{1}$ and Weijun Chen*1
}

\author{
Address: ${ }^{1}$ Beijing Institute of Genomics, Chinese Academy of Sciences, Airport industry B6, Beijing, 101300, PR China, ${ }^{2}$ State Key Laboratory of \\ Pathogen and Biosecurity, Institute of Microbiology and Epidemiology, Academy of Millitary Medical Sciences, Dongdajie Road 20, Beijing, \\ 100071, PR China, ${ }^{3} 302$ Hospital, Fengtai Road 26, Beijing 100853, PR China, ${ }^{4} 301$ Hospital, Fuxing Road 28, Beijing 100039, PR China and \\ ${ }^{5}$ Beijing Red Cross Blood Center, North middle Sanhuan Road 37, Beijing 100088, PR China \\ Email: Feng Mu - mufeng@genomics.org.cn; Dongsheng Niu - dsniu@bmi.ac.cn; Jingsong Mu - mujingsong@yahoo.com; \\ Bo He - heb@genomics.org.cn; Weiguo Han -wghan@bmi.ac.cn; Baoxing Fan - fanbxing@263.net; \\ Shengyong Huang - huangsy@genomics.org.cn; Yan Qiu - qiu444cn@yahoo.com.cn; Bo You - Youb@genomics.org.cn; \\ Weijun Chen* - chenwj@genomics.org.cn \\ * Corresponding author †Equal contributors
}

Published: 28 November 2008

BMC Microbiology 2008, 8:207 doi:10.1 I86/147|-2180-8-207
Received: 25 June 2008

Accepted: 28 November 2008

This article is available from: http://www.biomedcentral.com/I47I-2180/8/207

(C) 2008 Mu et al; licensee BioMed Central Ltd.

This is an Open Access article distributed under the terms of the Creative Commons Attribution License (http://creativecommons.org/licenses/by/2.0), which permits unrestricted use, distribution, and reproduction in any medium, provided the original work is properly cited.

\begin{abstract}
Background: In the absence of effective drugs, controlling SARS relies on the rapid identification of cases and appropriate management of the close contacts, or effective vaccines for SARS. Therefore, developing specific and sensitive laboratory tests for SARS as well as effective vaccines are necessary for national authorities.

Results: Genes encoding truncated nucleocapsid $(\mathrm{N})$ and spike $(\mathrm{S})$ proteins of SARSCoV were cloned into the expression vector PQE30 and fusionally expressed in Escherichia coli MI5. The fusion protein was analyzed for reactivity with SARS patients' sera and with anti-sera against the two human coronaviruses $\mathrm{HCOV} 229 \mathrm{E}$ and $\mathrm{HCoV}$ OC43 by ELISA, IFA and immunoblot assays. Furthermore, to evaluate the antigen-specific humoral antibody and T-cell responses in mice, the fusion protein was injected into 6-week-old BALB/c mice and a neutralization test as well as a Tcell analysis was performed. To evaluate the antiviral efficacy of immunization, BALB/c mice were challenged intranasally with SARSCoV at day 33 post injection and viral loads were determined by fluorescent quantitative RT-PCR. Serological results showed that the diagnostic sensitivity and specificity of the truncated $\mathrm{S}-\mathrm{N}$ fusion protein derived the SARS virus were $>99 \%(457 / 460)$ and $100.00 \%(650 / 650)$, respectively. Furthermore there was no cross-reactivity with other two human coronaviruses. High titers of antibodies to SRASCoV appeared in the immunized mice and the neutralization test showed that antibodies to the fusion protein could inhibit SARSCoV. The T cell proliferation showed that the fusion protein could induce an antigen-specific T-cell response. Fluorescent quantitative RT-PCR showed that BALB/c mice challenged intranasally with SARSCoV at day 33 post injection were completely protected from virus replication.
\end{abstract}

Conclusion: The truncated $\mathrm{S}-\mathrm{N}$ fusion protein is a suitable immunodiagnostic antigen and vaccine candidate. 


\section{Background}

The epidemic of severe atypical pneumonia, designated "severe acute respiratory syndrome (SARS)" by the World Health Organization (WHO) and first observed in Guangdong Province of China in November 2002, affected 8422 people and caused 916 deaths in 33 countries and areas worldwide up to August 7, 2003 [1,2]. A novel coronavirus, SARS-associated coronavirus $(S A R S C o V)$, was confirmed as the pathogen [3-6]. In the absence of effective drugs, controlling this disease relies on the rapid identification of cases and appropriate management of the close contacts, or effective vaccines against SARS. Therefore, the development of both specific and sensitive laboratory tests for SARS as well as effective vaccines is necessary for national authorities.

Laboratory tests for SARS based on indirect immunofluorescence assay (IFA) or viral particle lysate enzyme-linked immunosorbent assay (SARSCoV lysate ELISA) to detect antibodies against SARSCoV are important methods [7]. However, these methods both require cultivation of SARSCoV in a biosafety level 3 or 4 laboratory, which is both dangerous and difficult. Finding a suitable diagnostic test for this virus therefore remains a high priority. A practical approach towards this goal is to clone and express the immunodominant genes of SARSCoV.

Several studies have shown that most of the antigenic epitopes of SARSCoV are located on the nucleocapsid $(\mathrm{N})$ and spike (S) proteins and that the latter protein has an important role in viral entry and pathogenesis [8-12]. Other data have shown that the viral $\mathrm{N}$ and $\mathrm{S}$ proteins of coronaviruses could induce a specific $\mathrm{T}$ cell response [1316]. Here, we report the cloning and expression of a truncated S-N fusion protein of SARSCoV and the investigation of its antigenicity and immunogenicity.

\section{Methods \\ Viruses and vectors}

The $p Q E 30$ vector was purchased from Qiagen (Qiagen GmbH, Hilden, Germany). Escherichia coli M15 was used as host strain for the vector. The following virus strains were kindly provided by the Academy of Military Medical Science and the National Institute for the Control of Pharmaceutical and Biological Products: The SARSCoV (BJ01); SARSCoV (GD01); human coronavirus 229E (HCoV229E) and human coronavirus OC43 (HCoVOC43). All work with infectious virus was performed in a biosafety level 3 laboratory.

\section{Construction of recombinant expression plasmids}

Viral RNA was extracted with TRIzol according to manual (Invitrogen). All primers were synthesized by the Shanghai Sangon Company according to the published DNA sequences (table 1). Genomic SARSCoV sequences for $\mathrm{N}$ protein as well as for truncated N (321-422aa) and S (264680aa) proteins were amplified by RT-PCR in a mixture of $200 \mu \mathrm{M}$ (each) deoxynucleoside triphosphate, $0.3 \mu \mathrm{M}$ (each) primer, $1 \mathrm{U}$ of Taq polymerase (Takara) in $10 \mathrm{mM}$ Tris-HCl buffer ( $\mathrm{pH}$ 8.3) supplemented with $2.0 \mathrm{mM}$ $\mathrm{MgCl}_{2}$ and $50 \mathrm{mM} \mathrm{KCl}$. The PCR reactions were started with $10 \mathrm{~min}$ at $95^{\circ} \mathrm{C}$ and followed by 35 cycles, with 1 cycle consisting of $45 \mathrm{sec}$ at $94^{\circ} \mathrm{C}, 30 \mathrm{sec}$ at $55^{\circ} \mathrm{C}$, and 60 sec at $72^{\circ} \mathrm{C}$. A final step of $5 \mathrm{~min}$ at $72^{\circ} \mathrm{C}$ was added to the last cycle. The fusion gene construct was established for expression of a truncated $\mathrm{S}-\mathrm{N}$ fusion protein. The recombinant plasmids were constructed as described elsewhere [17]. All restriction enzymes and ligases were purchased from TaKaRa biotechnology Co., Ltd (Dalian, China). E. coli M15 was transformed with ligation mixtures and the control vector, respectively. The presence of the target genes in the recombinant plasmids was verified by gene-specific PCR and sequence analysis.

Table I: Primers used for target gene by RT-PCR

\begin{tabular}{|c|c|c|}
\hline Primer $^{\mathrm{a}}$ & Primer sequences ${ }^{b}$ & PCR product (bp) \\
\hline SARS-Nf-4 & $5^{\prime}-$ cgc ggatcctct gat aat gga ccc ca $-3^{\prime}$ & 1266 \\
\hline SARS-Nr-1269 & $5^{\prime}-$ gc ctgcagtta tgc ctg agt tga atc agc aga $-3^{\prime}$ & \\
\hline 229E-Nf-4 & $5 '-$ cgc ggatccgct aca gtc aaa tgg gct gat $-3^{\prime}$ & 1167 \\
\hline 229E-Nr-I I70 & $5^{\prime}-$ ccc gtcgactta gtt tac ttc atc aat tat $-3^{\prime}$ & \\
\hline OC43-Nf-4 & $5^{\prime}-$ cgc ggatcctct ttt act cct ggt aag caa $-3^{\prime}$ & 1344 \\
\hline OC43-Nr-1347 & $5^{\prime}-\operatorname{ccc}$ a agctttta tat ttc tga ggt gtc ttc $-3^{\prime}$ & \\
\hline SARS-tNf-96I & $5 '-$ cgc ggtaccatt ggc atg gaa gtc aca $-3^{\prime}$ & 309 \\
\hline SARS-tNr-1269 & $5^{\prime}-$ ccc ctgcagtta tgc ctg agt tga atc agc aga $-3^{\prime}$ & \\
\hline $229 \mathrm{E}-\mathrm{t} N f-925$ & 5 - cgc ggatccgtt tcc aaa gag tca ggc aac -3 ' & 246 \\
\hline $229 \mathrm{E}-\mathrm{tNr}-1170$ & 5 - ccc gtcgactta gtt tac ttc atc aat tat $-3^{\prime}$ & \\
\hline OC43-tNf-985 & 5 - cgc ggatcctta gag ttg gcc aaa gtg $-3^{\prime}$ & 363 \\
\hline OC43-tNr-1347 & 5 - ccc aagctttta tat ttc tga ggt gtc ttc $-3^{\prime}$ & \\
\hline SARS-tSf-790 & 5'- cgc ggatccctc aag tat gat gaa aat ggt aca atc aca $-3^{\prime}$ & $125 \mid$ \\
\hline SARS-tSr-2040 & $5^{\prime}-$ gc ggtaccaga cat agt ata agc cac aat aga $-3^{\prime}$ & \\
\hline
\end{tabular}

a $f$ and $r$ signify forward and reverse primers, respectively.

b underlined sequences indicate restriction sites: BamHI (ggatcc), Pstl (ctgcag), Sall (gtcgac), HindIII (aagctt), and Kpnl (ggtacc). 


\section{Expression and purification of the recombinant proteins} The materials and methods used for obtaining the recombinant proteins were described in detail elsewhere [17]. The transformed bacteria were induced with $2.0 \mathrm{mM}$ IPTG at $37^{\circ} \mathrm{C}$ and inclusion bodies containing recombinant proteins with $\mathrm{N}$-terminal sequences of six consecutive His residues were serially extracted with $2 \mathrm{M}$ urea and then dissolved in $8 \mathrm{M}$ urea. It was then subjected to purification by means of a Ni-NTA Affinity Chromatography Purification Kit according to manual (Qiagen $\mathrm{GmbH}$ ). Recovery of purified and renatured recombinant proteins from the denatured state in $8 \mathrm{M}$ urea in buffer A $(10 \mathrm{mM}$ Tris-Cl (pH 7.0), $100 \mathrm{mM} \mathrm{NaH} \mathrm{PO}_{4}$ ) was achieved by sequential dialysis against $6 \mathrm{M}, 4 \mathrm{M}$ and $2 \mathrm{M}$ urea in buffer $\mathrm{A}$ and finally against buffer A only. In detail, the products were dialyzed twice against 5 volumes of $6 \mathrm{M}$ urea in buffer A for $30 \mathrm{~min}$ at room temperature. The same procedure was repeated with $4 \mathrm{M}$ urea and $2 \mathrm{M}$ urea in buffer $\mathrm{A}$. The final dialysis was against buffer A with two initial changes of buffer after $30 \mathrm{~min}$ each and a final dialysis overnight at $4^{\circ} \mathrm{C}$. The purity of the target proteins was determined by SDS-PAGE [18], see Figure 1.

\section{Human sera}

SARS patients' sera: 460 serum samples from SARS convalescents (from 35 to 114 days after the onset of illness) fulfilling the clinical WHO case definition of SARS, and whose diagnosis was subsequently confirmed by seroconversion, were collected in 301 Hospital (Beijing, China) and 302 Hospital (Beijing, China). All sera were tested

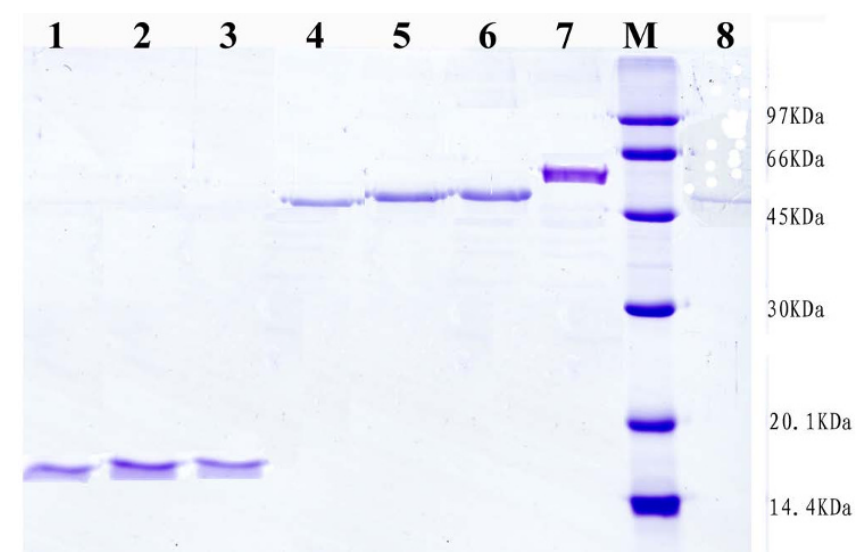

\section{Figure I}

SDS-PAGE analysis of the expression and purification target proteins. Lane I: purified HCoV229E truncated N protein; Lane 2: purified SARSCoV truncated N protein; Lane 3: purified HCoVOC43 truncated $\mathrm{N}$ protein; Lane 4: purified HCoV229E N protein; Lane 5: purified SARSCoV N protein; Lane 6: purified HCoVOC43 N protein; Lane 7: purified SARSCoV truncated S-N fusion protein; Lane 8: purified SARSCoV truncated S protein; Lane M: protein molecular weight marker. positive by the SARSCoV lysate ELISA IgG Kit (Beijing BGIGBI Biotech Corp.), which has been approved by the State Food and Drug Administration (SFDA) for the detection of anti-SARSCoV immunoglobulin (Ig) G antibody from human serum or plasma specimens.

\section{Control sera}

Sera from 650 Healthy blood donors were collected by the Beijing Red Cross blood center from May to October 2003.

\section{Mouse Sera}

Polyclonal mouse sera against SARSCoV (BJ01), HCoV $229 \mathrm{E}$ and $\mathrm{HCoV}$ OC43 were prepared in our laboratory (IFA dilution: 1:5120, 1:5120, 1:10240, respectively) as were polyclonal mouse sera against purified recombinant proteins SARSCoV N, HCoV OC43 N, HCoV 229E N (IFA dilution: 1:5120, 1:2560, 1:5120, respectively). Control sera were collected from healthy BALB/c mice.

\section{Immunization}

Mouse immunization was performed according to established protocols [19]. Briefly, sixteen 6-week-old BALB/c mice were divided into 2 groups and injected subcutaneously with $0.1 \mathrm{~mL}$ of purified recombinant fusion truncated S-N protein solution $(100 \mu \mathrm{g} / \mathrm{mL})$ and PBS, respectively, both mixed with an equal volume of paraffin oil. Immunized mice were boosted after 24 days using the half dose of antigen by celiac arterial route.

\section{Immunological analyses}

Immunoblot analysis

An immunoblot analysis was performed as described in detail elsewhere [18]. SDS-PAGE analysis was performed using the Mini-protein 3 Electrophoresis System (BIORAD). The stacking gel and separation gel contained 5\% and 15\% acrylamide, respectively. Electrophoresis was carried out at a constant voltage of $120 \mathrm{~V}$ for $180 \mathrm{~min}$. The proteins were electroblotted onto nitrocellulose membranes. The mouse sera were then tested against each of the recombinant proteins.

IFA

An indirect immunofluorescence assay (IFA) was performed to detect antibodies to SARSCoV (BJ01), HCoV $229 \mathrm{E}$ and $\mathrm{HCoV}$ OC43 by using SARSCoV according to established protocols [20].

\section{ELISA}

Microtiter plates (96 wells, Shenzhen Jinchanhua Co. Ltd) were coated overnight at $4{ }^{\circ} \mathrm{C}$ with either of the eight recombinant antigens (four recombinant antigens of $S A R S C o V$ : truncated S protein, N protein, truncated N protein, and truncated S-N fusion protein; two recombinant antigens of HCoV229E: truncated N protein, N protein; 
two recombinant antigens of $\mathrm{HCoVOC} 43$ : truncated $\mathrm{N}$ protein, $\mathrm{N}$ protein) diluted in $50 \mathrm{mM} \mathrm{NaHCO}$ buffer $(\mathrm{pH}$ 9.6). Each well was rinsed with PBS (phosphate-buffered saline) containing $0.05 \%$ Tween-20 and 3\% BSA for blocking the remaining protein-binding sites. After incubation at $37^{\circ} \mathrm{C}$ for 1 hour, the plates were washed five times with the PBS/Tween-20 buffer. Diluted serum samples (1:10 with PBS) were added to the plates. The plates were incubated at $37^{\circ} \mathrm{C}$ for $30 \mathrm{~min}$ and washed five times with the PBS/Tween-20 buffer. After addition of peroxidase-conjugated goat anti-human IgG (diluted 1:2000 in PBS supplemented with $0.5 \%$ of Tween-20 and $1.5 \%$ of BSA) to each well and the plates were incubated at $37^{\circ} \mathrm{C}$ for $30 \mathrm{~min}$, then washed five times with the PBS/Tween20 buffer before the addition of tetramethyl-benzidine (TMB)/hydrogen peroxide substrate. Reaction was stopped by addition of $2 \mathrm{M} \mathrm{H}_{2} \mathrm{SO}_{4}$. The $\mathrm{OD}_{450 / 630}$ value was measured with a microtiter plate reader in triplicates. A blank control, a negative control and a positive control were always included on each plate. The cut-off values for IgG were 0.16 (three $\mathrm{N}$ proteins), 0.12 (truncated $\mathrm{S}$ protein), 0.14 (three truncated $N$ proteins), 0.12 (truncated $S$ $\mathrm{N}$ protein), respectively, which were calculated as the mean +2 SD of the readings given by 1000 blood donor control sera collected from 2001 to 2002 in Beijing. Samples were tested again in triplicates when their $\mathrm{OD}_{450 / 630}$ values were near the cut-off values. For the detection of mice antibodies, all procedures were the same as for detection of human antibodies except that peroxidase-conjugated goat anti-mice IgG diluted to 1:1000 was used. Mice sera were diluted to 1:20 with PBS.

\section{Neutralization test}

Neutralizing titer (NT) of mouse sera was measured by a rapid microneutralization assay [21]. In brief, heat-inactivated $\left(55^{\circ} \mathrm{C}\right.$ for $\left.30 \mathrm{~min}\right)$ mouse immune serum was diluted tenfold and then serially diluted twofold to 1:2560 in DMEM (Gibco) containing 5\% heat-inactivated fetal calf serum $\left(56^{\circ} \mathrm{C}\right.$ for $\left.30 \mathrm{~min}\right)$. Approximately $50 \mu \mathrm{L}$ of SARSCoV (BJ01 strain) (400 TCID $\left._{50} / 100 \mu \mathrm{L}\right)$ was mixed with an equal volume of diluted serum and incubated at $35^{\circ} \mathrm{C}$ for $1 \mathrm{~h}$; then $50 \mathrm{uL}$ of the mixture (containing $100 \mathrm{TCID}_{50}$ ) and $50 \mu \mathrm{L}$ of DMEM containing $5 \%$ inactivated fetal calf serum were added onto a VeroE6 cell monolayer in triplicate. The viral cytopathic effect (CPE) was observed on days 2 and 3 . The dilution of serum that completely prevented CPE in $50 \%$ of the wells was calculated according to the Reed Muench formula [22].

\section{Cross-reactivity among viruses and recombinant proteins}

Serological cross-reactivity among different human coronaviruses was tested by incubation of SARSCoV-infected cells with mouse antisera against the two other human coronaviruses, HCoV229E and HCoVOC43, and subsequent indirect immunofluorescence assay (IFA). To evalu- ate cross-reactivity among different recombinant proteins of the three human coronaviruses, the proteins were subjected to immunoblot assays with mouse antisera against the proteins as well as antisera against the viruses and were also subjected to ELISA with 460 serum samples from SARS convalescents as well as mice antisera against the viruses.

\section{Immune responses to the truncated SARSCoV S-N fusion protein}

Humoral immune response

Serum samples were collected from the tail veins every 3 days after the initial immunization and the final serum samples were collected from the orbital plexus for antibody level assessment by the SARSCoV lysate ELISA IgG Kit according to the manufacturer's instruction, except that peroxidase-conjugated goat anti-human IgG was substituted by peroxidase-conjugated goat anti-mouse IgG (Sihuan Sci-Technics Company, Beijing). A value of $\mathrm{S} / \mathrm{N} \geq$ 2.1 was taken as positive standard.

\section{Spleen lymphocyte immune response}

The proliferation of spleen lymphocytes was measured by colorimetric analysis described previously [23]. Four $\mathrm{BALB} / \mathrm{c}$ mice in each group were killed on day 33 after immunization and their spleens were ground into singlecell suspensions in RPMI 1640 medium (Gibco) supplemented with $10 \%$ fetal calf serum. The suspensions were mixed with 5 volumes of erythrocyte lysis buffer $(0.01 \mathrm{M}$ Tris- $\mathrm{HCl} \mathrm{pH} \mathrm{7.6;0.01} \mathrm{M} \mathrm{NaCl;} 0.005 \mathrm{M} \mathrm{MgCl}_{2}$ ), incubated for 10 minutes on ice and centrifuged at $400 \mathrm{~g}$ for 5 $\min$ at $4^{\circ} \mathrm{C}$. The pellets were resuspended in RPMI 1640 medium (Gibco) supplemented with $10 \%$ fetal calf serum. They were seeded in triplicates in flat-bottom 96well microtiter plates (Costar) with $5 \times 10^{5}$ cells per well in $100 \mu \mathrm{L}$ of culture medium with purified and truncated S-N protein at $10,3,1,0.3$ and $0 \mu \mathrm{g} / \mathrm{mL}$, respectively. After incubation for 3 days with $5 \% \mathrm{CO}_{2}$ at $37^{\circ} \mathrm{C}, 10 \mu \mathrm{L}$ of a solution of the tetrazolium salt 3-(4,5-dimethylthiazol-2yl)-2,5-diphenyltetrazolium bromide (MTT) was added to each well, and the plates were incubated for $4 \mathrm{~h}$ at $37^{\circ} \mathrm{C}$. One hundred microliter of lysis buffer containing $10 \%$ Triton-50\% isopropanol-0.01 M hydrochloric acid was then added to each well, and the plates were incubated overnight. The optical densities at $570 \mathrm{~nm}\left(\mathrm{OD}_{570}\right)$ and at $630 \mathrm{~nm}\left(\mathrm{OD}_{630}\right)$ were measured.

\section{SARSCoV challenge and determination of virus load}

Four BALB/c mice from each group, immunized as well as controls, were challenged intranasally with $10^{4} \mathrm{TCID}_{50}$ of the SARSCoV GD01 strain on day 33 after immunization to tested the heterologous protection. After two days of clinical observation the mice were sacrificed and their lungs were collected for determination of the level of viral RNA. 
Fifty mg lung tissue was first homogenized in liquid nitrogen and then in $1 \mathrm{~mL}$ of TRIzol. Tissue homogenates were clarified by low-speed centrifugation (3000 rpm). RNA extraction was performed according to manual (Invitrogen). Virus loads were determined by fluorescent quantitative RT-PCR and expressed as number of copies per gram tissue [24].

\section{Results \\ Serological cross-reactivity among coronaviruses and recombinant proteins}

The result of immunofluorescence analysis of cross-reactivity between SARSCoV-infected cells and mouse antisera against each $\mathrm{N}$ protein of the three coronaviruses is shown in Figure 2. The results show that mouse anti-sera to HCoV229E N protein and HCoVOC43 N protein crossreact with $S A R S C o V$. Figure 3 shows the result of immunoblot analyses for cross-reactions between (i) intact $\mathrm{N}$ protein from the three human coronaviruses plus the truncated $S$ protein and mouse antisera against each coronavirus (panels A, B, and C) and (ii) truncated $\mathrm{N}$ protein from each coronavirus and mouse antisera against each coronavirus (panels D, E and F). The results showed (a) cross-reactions between the intact $\mathrm{N}$ proteins and the antisera against the three coronaviruses and (b) no crossreaction between the antisera and the truncated proteins. The recombinant proteins of $\mathrm{HCoV} 229 \mathrm{E}$ and $\mathrm{HCoVOC} 43$ were also tested with 460 serum samples from SARS convalescents by ELISA. The results showed 34 and 21 sera

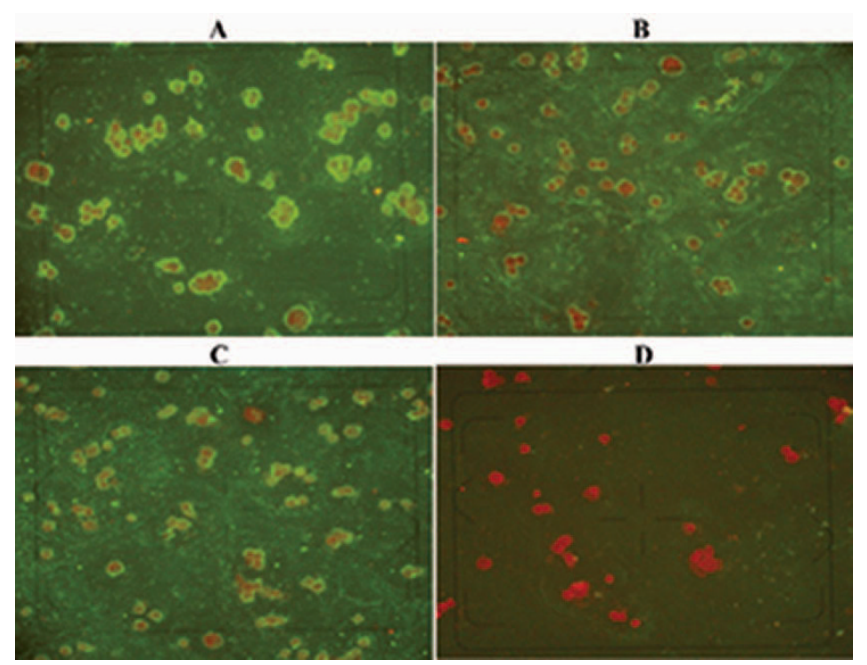

Figure 2

IFA analysis of cross-reaction of the SARSCoV infected cell using mouse anti-sera to recombinant $\mathbf{N}$ proteins of other two human Coronaviruses. A: Reacted with mouse anti-serum to SARSCoV N protein; B: Reacted with mouse anti-serum to HCoV229E N protein; C: Reacted with mouse anti-serum to $\mathrm{HCoVOC} 43 \mathrm{~N}$ protein; D: Reacted with mouse serum from controls injected with PBS; were tested positive by $\mathrm{N}$ proteins of HCoVOC43 and HCoV229E respectively, while none of the sera were tested positive by both truncated N proteins of HCoVOC43 and HCoV229E.

\section{Diagnostic sensitivity and specificity of ELISA with truncated S-N fusion protein as antigen}

The qualities of truncated $S$ protein, $N$ protein, truncated $\mathrm{N}$ protein and truncated $\mathrm{S}-\mathrm{N}$ fusion protein as diagnostic antigens were evaluated by ELISA technique as described in Materials and Methods. All 460 SARS patients' sera were tested against all four antigens. Only 3 samples were tested negative in the truncated $\mathrm{S}-\mathrm{N}$ fusion protein assay, whereas 62, 38 and 43 samples were tested negative in the truncated $\mathrm{S}$ protein, $\mathrm{N}$ protein and truncated $\mathrm{N}$ protein assays, respectively (Table 2). Compared with SARSCoV lysate ELISA, the sensitivity of ELISA with truncated S protein, $\mathrm{N}$ protein, truncated $\mathrm{N}$ protein and truncated $\mathrm{S}-\mathrm{N}$ fusion protein as antigens were 86.5\% (398/460), 91.7\% (422/460), 90.7\% (417/460) and > 99\% (457/460), respectively. To evaluate the specificity of these assays, the sera of the 650 healthy people were tested. Only a few gave a positive reaction with either SARSCoV lysate or $\mathrm{N}$ protein, whereas none reacted against the truncated proteins (Table 2). To further evaluate the specificity of the truncated S-N fusion protein, the polyclonal mouse sera against SARSCoV (BJ01), HCoV229E and HCoVOC43 antisera to were tested by ELISA. Only mice antiserum against SARSCoV(BJ01) tests positive.

\section{Specific humoral and cellular anti- SARSCoV immune responses to the truncated $\mathrm{S}-\mathrm{N}$ fusion protein}

Sera antibody tests showed the ability of the fusion protein to induce the generation of SARS-specific antibodies in the immunized mice. Nine to twelve days after injection, the specific Ig G antibody could be detected. To test whether the mouse sera against the truncated S-N protein were able to neutralize SARSCoV, a property that is likely to be crucial in the defense against virus infection, the SARSCOV BJ01 strain was used in a microneutralization assay as described in Materials and Methods. The serum titer of neutralizing antibodies against SARSCoV was $2.425 \pm 0.209(\mathrm{Lg}$ dilution $\pm \mathrm{SD})$

The lymphocytes proliferation assay showed that the truncated S-N protein could induce T cell proliferation of mice immunized with the truncated fusion protein (Table 3). There are significant differences between mice immunized with the truncated fusion protein and the controls ( $\mathrm{t}$ test $p=0.0084<0.05)$.

\section{Protection from SARSCoV challenge and virus replication} No clinical signs of illness were observed in either group of SARS-challenged mice. The analysis for SARSCoV genome copies in the lungs of immunized mice and con- 


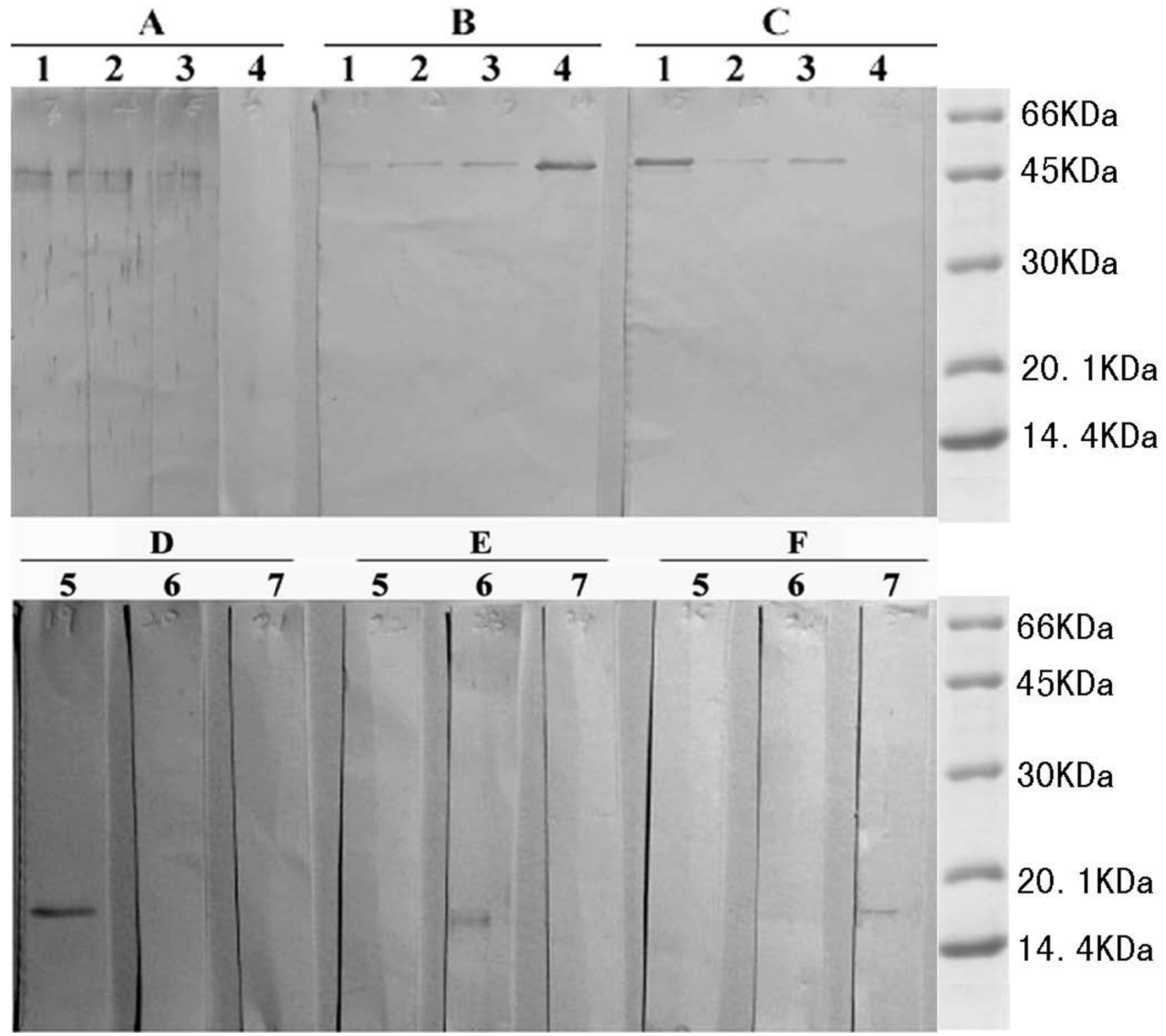

\section{Figure 3}

Immunoblot assay analysis of cross-reaction of the coronaviruses recombinant proteins using mouse anti-sera to three different human Coronaviruses and recombinant proteins. A: Reacted with mouse anti-serum to HCoV229E; B: Reacted with mouse anti-serum to SARSCoV; C: Reacted with mouse anti-serum to HCoVOC43; Lane I: Purified HCoV229E N protein; Lane 2: Purified HCoVOC43 N protein; Lane 3: Purified SARSCoV N protein; Lane 4: Purified SARSCoV truncated S protein; D: Reacted with mouse anti-serum to SARSCoV; E: Reacted with mouse anti-serum to HCoV229E; F: Reacted with mouse anti-serum to HCoVOC43; Lane 5: Purified SARSCoV truncated N protein; Lane 6: Purified HCoV229E truncated N protein; Lane 7: Purified HCoVOC43 truncated $\mathrm{N}$ protein.

trols was performed. The mean of virus genome copy numbers are $20708 \pm 6202$ (copies/g \pm SD) per 1 gram lung tissue in the control group, whereas virus loads in mice immunized with truncated S-N protein were below the limit of detection.

\section{Discussion}

SARS, a newly emerged infectious disease which caused worldwide outbreak in 2003, has been a crucial public health problem. Establishing specific and convenient laboratory tests for SARS and finding a vaccine for this virus are of high priority. 
Table 2: Antibody detection rates for recombinant protein ELISA and SARSCoV lysate ELISA of sera from SARS patients and healthy controls.

\begin{tabular}{ccccc}
\hline Coating antigen & \multicolumn{2}{c}{ Sera of SARS patients } & & \multicolumn{2}{c}{ Sera of healthy blood donors } \\
\cline { 2 - 4 } & Positive & negative & & Positive \\
\hline SARSCoV lysate & 460 & 0 & 5 & 645 \\
truncated S protein & 398 & 62 & 0 & 650 \\
N protein & 422 & 38 & 8 & 642 \\
truncated N protein & 417 & 43 & 0 & 650 \\
truncated S-N protein & 457 & 3 & 0 & 650 \\
\hline
\end{tabular}

Previous data have shown a high degree of sequence similarity between the nucleocapsid $(\mathrm{N})$ proteins of coronaviruses and demonstrated serious serological crossreactions $[25,26]$. We aligned the $\mathrm{N}$ protein of five human coronaviruses (SARSCoV, HCoV229E, HCoVNL63, HCoVOC43 and HCoVHKU1) and found several fairly homologous regions, e.g. SARSCoV 57-210aa, 258-320aa. In these regions, the N protein of SARSCoV is 35-39\% identical in amino acid sequence to the $\mathrm{N}$ protein of $\mathrm{HCoV}$ 229E and $\mathrm{HCoV}$ NL63 and $47-50 \%$ identical in amino acid sequence to that of HCoVOC43 and HCoVHKU1 (Figure 4). We also found that the C-terminal of the $\mathrm{N}$ protein (SARSCoV 321-422aa) has lower identity in amino acid sequence among these human coronaviruse (Figure 4). In addition, our previous research showed that some unique highly antigenic sites are located in the Cterminal part of the SARS N protein and in the 270-667aa of the SARS spike (S) protein [8]. Other research also showed that the C-terminal part of the SARS $\mathrm{N}$ protein was highly antigenic [27]. In the present study, using the $p Q E 30$ expression vector we cloned the $\mathrm{N}$ genes, gene segments encoding the C-terminal parts of the $\mathrm{N}$ proteins from all three coronaviruses, as well as SARSCoV gene segments encoding a truncated spike protein (264-680 aa) and a truncated S-N fusion protein, respectively. All proteins were highly expressed in E. coli M15. To evaluate the cross-reactivity of these recombinant proteins and viruses, IFA and immunoblot assays were performed. The results (Figures 2 and 3 ) showed that the truncated proteins only reacted with species-specific antiserum while the $\mathrm{N}$ proteins cross-reacted as did the viruses. The further ELISA results also showed that the intact $\mathrm{N}$ proteins of HCoV229E and HCoVOC43 cross-reacted with SARS patients' sera $(21 / 460,34 / 460$ respectively) while the truncated $\mathrm{N}$ proteins did not cross-react with SARS patients' sera.

Using the purified proteins as antigens in ELISA assays for antibodies in the sera of SARS patients we found that the assay using truncated S-N fusion protein has a clearly higher sensitivity than those using intact $\mathrm{N}$ protein or truncated $\mathrm{S}$ and $\mathrm{N}$ proteins, and virtually as high as the assay using whole SARSCoV lysate (Table 2). The results indicated the $\mathrm{N}$ and $\mathrm{S}$ protein were complementary in detecting SARS-specific antibodies. This is consistent with previous studies $[28,29]$. Five positive sera to SARSCoV lysate antigen were all tested positive against SARSCoV N protein but negative against SARSCoV truncated N-S protein. These sera were also tested positive against $\mathrm{N}$ proteins of HCoV229E and HCoVOC43 (data not shown), which could be reasonably explained partly by existence of other $\mathrm{HCoV}$ infections in these humans. The truncated $\mathrm{S}-\mathrm{N}$ fusion protein was also subjected to ELISA with mice antisera against SARSCoV (BJ01), HCoV229E and HCoVOC43. Only mice antiserum against SARSCoV(BJ01) tests positive. These results showed that the SARSCoV truncated N-S protein had high specificity. Considering the difficulty of SARSCoV lysate antigen pro-

Table 3: Effects of recombinant protein on spleen cell proliferation in mice injected with recombinant proteins and a control group of mice injected with PBS by MTTa

\begin{tabular}{lccccc}
\hline Group & \multicolumn{5}{c}{ Proliferation $\left(\mathrm{D}\right.$ value $\left.\mathrm{e}^{\mathrm{b}} \pm \mathrm{SD}\right)$ with the following concentration $(\mu \mathrm{g} / \mathrm{ml})$ of recombinant proteins } \\
\cline { 2 - 6 } & 10 & 3 & 1 & 0.3 & 0 \\
\hline PBS Control & $0.116 \pm 0.112$ & $0.074 \pm 0.046$ & $0.011 \pm 0.002$ & $0.022 \pm 0.008$ & $0.043 \pm 0.008$ \\
truncated S-N & $0.603 \pm 0.118$ & $0.551 \pm 0.019$ & $0.542 \pm 0.216$ & $0.476 \pm 0.274$ & $0.068 \pm 0.021$ \\
\hline
\end{tabular}

a Four BALB/c mice of each group were killed. Spleens were harvested and lymphocyte cultures (Three repeats) were stimulated in vitro for 3 days with medium or with various concentrations of purified recombinant fusion truncated S-N protein (three repeats). The truncated S-N protein could induce $T$ cell proliferation and significant differences were found between the groups of mice immunized with recombinant protein or injected with PBS ( $T$ test $P=0.0084<0.05)$.

b Value $=D_{570}-D_{630}$-blank 


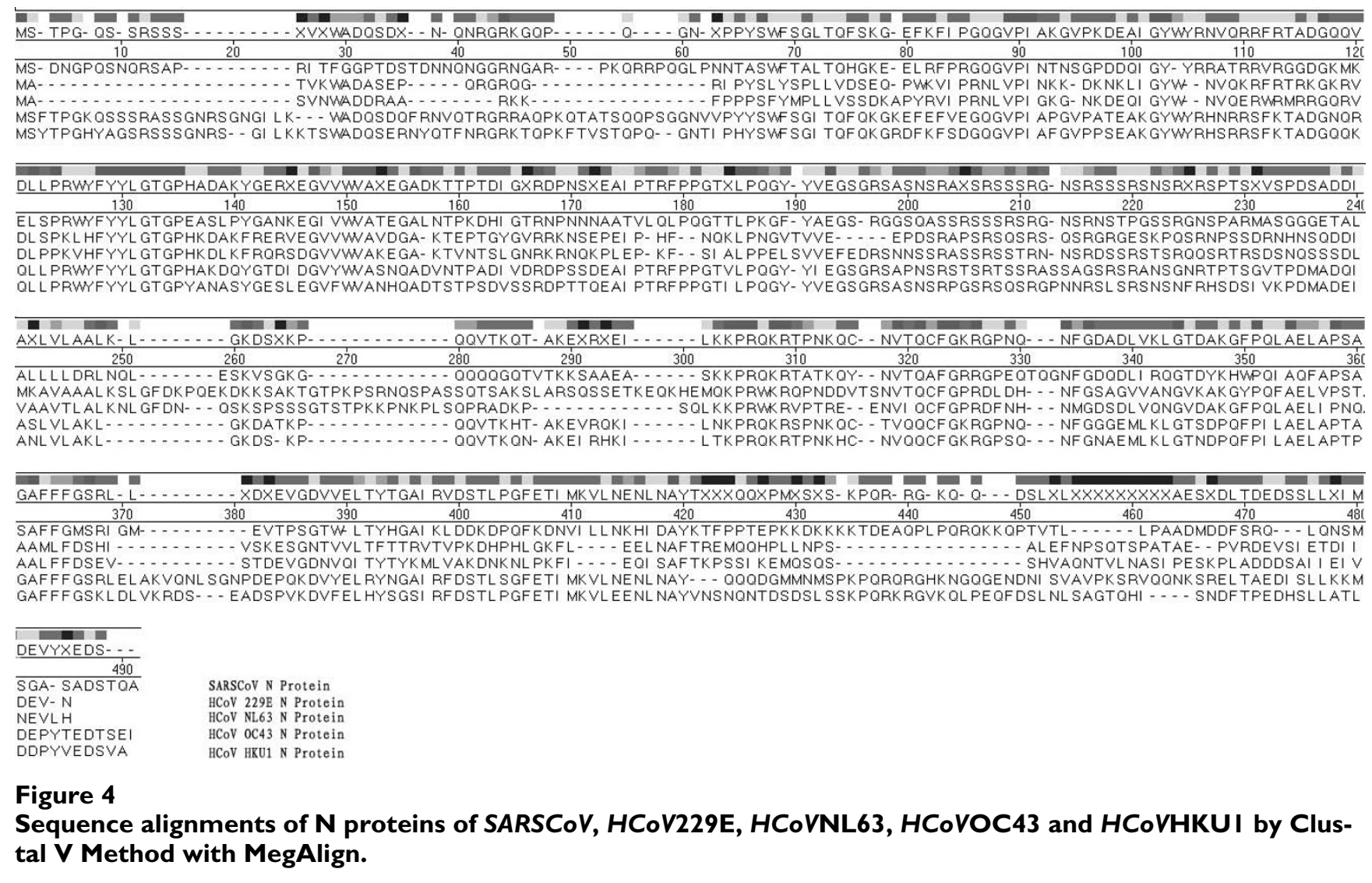

duction and its false positive ratio ( $\sim 0.77 \%$, Table 2$)$, the truncated S-N fusion protein is a suitable diagnostic antigen for detection of SARSCoV antibodies.

The S protein of SARSCoV is an important determinant of tissue tropism, as it mediates virus and cellular membrane fusion. Analysis of neutralizing epitopes showed that the receptor-binding region of the $S$ protein plays an important role in virus infection $[12,30,31]$. A DNA vaccine study of SARSCoV has also shown that the $S$ protein can induce protective immune responses to SARSCoV [32]. Moreover, some data showed that the $\mathrm{N}$ protein of SARSCoV could induce specific T-cell responses and studies of animal coronaviruses have suggested that both cellular and humoral immunity contribute to protection during persistent infection $[13,16,33]$. Considering that our fusion protein includes the receptor-binding region of the $S$ protein and immunodominant T-cell epitopes of the $\mathrm{N}$ protein, we also investigated the role of the truncated $\mathrm{S}$ $\mathrm{N}$ protein in anti-SARSCoV infection. Seven to nine days after injection of the fusion protein, the mice began to show seropositive for SARS antibodies. After the first booster, all mice generated high titer of SARS-specific antibodies and the antibodies could neutralize the SARSCoV infectivity. In the lymphocytes proliferation assay, the truncated S-N protein could induce $\mathrm{T}$ cell proliferation
(Table 3). Compared to the control group, the mice immunized with the truncated $\mathrm{S}-\mathrm{N}$ protein were protected from SARSCoV challenge, as indicated by a lack of detectable viral RNA. Therefore, in addition to being a valuable diagnostic antigen the truncated $\mathrm{S}-\mathrm{N}$ fusion protein is a potential candidate for the development of a SARS subunit vaccine.

\section{Conclusion}

The truncated S-N fusion protein has high sensitivity and specificity and it is a suitable diagnostic antigen for detection of SARSCoV antibodies. On the other hand, it could induce the mice generated high titer of SARS-specific neutralizing antibodies and $\mathrm{T}$ cell proliferation. The mice immunized with the truncated S-N protein were protected from SARSCoV challenge. It is also a potential candidate for the development of a SARS subunit vaccine.

\section{Competing interests}

The authors declare that they have no competing interests.

\section{Authors' contributions}

FM carried out the genes cloning and protein expression and drafted the manuscript. DSN carried out the Viruses challenge assays and partial immunoassays. JSM carried out clinical samples collection and partial immunoassays. 
BH, WGH, SYH and BY participated in the samples detection. BXF and YQ participated in the samples collection. WJC designed the study, perform the data analysis and wrote the manuscript. All authors read and approved the final manuscript.

\section{Acknowledgements}

We thank Drs. Xiuqing Zhang critical reading of the manuscript. We thank research funding from the National High Technology Research and Development Program of China (863 Program) 2003AA2082 I6 from Ministry of Science and Technology, the People's Republic of China and from Chinese Academy of Sciences.

\section{References}

I. WHO: Cumulative number of reported cases of severe acute respiratory syndrome (SARS). 2003 [http://www.who.int/csrl sars/country/2003 08 /5/en/].

2. WHO: Severe acute respiratory syndrome (SARS). Wkly Epidemiol Rec 2003, 78:86.

3. Marra MA, Jones SJM, Astell CR, Holt RA, Wilson AB, Butterfield YSN, Khattra J, Jennifer KA, Barber SA, Chan SY, Cloutier A, Coughlin SM, Freeman D, Girn N, Griffith OL, Leach SR, Mayo M, McDonald H, Montgomery SB, Pandoh PK, Petrescu AS, Robertson AG, Schein JE, Siddiqui A, Smailus DE, Stott JM, Yang GS: The Genome sequence of the SARS-associated coronavirus. Science 2003, 300:1399-1404.

4. Peiris JS, Lai ST, Poon LL, Guan Y, Yam LY, Lim W, Nicholls J, Yee WK, Yan WW, Cheung MT, Cheng VC, Chan KH, Tsang DN, Yung $\mathrm{RW}, \mathrm{Ng} \mathrm{TK}$, Yuen KY, SARS study group: Coronavirus as a possible cause of severe acute respiratory syndrome. Lancet 2003, 36I:1319-1325.

5. Qin E, Zhu Q, Yu M, Fan B, Chang G, Si B, Yang B, Peng W, Jiang T, Liu B, Deng Y, Liu H, Zhang Y, Wang C, Li Y, Gan Y, Li X, Lü F, Tan G, Cao W, Yang R, Wang J, Li W, Xu Z, Li Y, Wu Q, Lin W, Han Y, $\mathrm{Li} \mathrm{G}, \mathrm{Li} W$, et al.: A complete sequence and comparative analysis of a SARS-associated virus (Isolate BJOI). Chin Sci Bulltin 2003, 48:94I-948.

6. Rota PA, Oberste MS, Monroe SS, Nix WA, Campagnoli R, Icenogle $J$, Peñaranda S, Bankamp B, Maher K, Chen MH, Tong S, Tamin A, Lowe L, Frace M, DeRisi JL, Chen Q, Wang D, Erdman DD, Peret TC, Burns C, Ksiazek TG, Rollin PE, Sanchez A, Liffick S, Holloway B, Limor J, McCaustland K, Olsen-Rasmussen M, Fouchier R, Günther S, et al.: Characterization of a novel coronavirus associated with severe acute respiratory syndrome. Science 2003, 300:1394-1399.

7. Chen W, Xu Z, Mu J, Yang L, Gan H, Mu F, Fan B, He B, Huang S, You $B$, Yang $Y$, Tang $X$, Qiu L, Qiu Y, Wen J, Fang J, Wang J: Antibody response and viraemia during the course of severe acute respiratory syndrome (SARS)-associated coronavirus infection. Journal of Medical Microbiology 2004, 53:435-438.

8. Wang J, Wen J, Li J, Yin J, Zhu Q, Wang H, Yang Y, Qin E, You B, Li W, Li X, Huang S, Yang R, Zhang $X$, Yang L, Zhang T, Yin Y, Cui $X$, Tang X, Wang L, He B, Ma L, Lei T, Zeng C, Fang J, Yu J, Wang J, Yang $\mathrm{H}$, West MB, Bhatnagar A, et al:: Assessment of Immunoreactive Synthetic Peptides from the Structural Proteins of Severe Acute Respiratory Syndrome Coronavirus. Clinical Chemistry 2003, 49(I 2): 1989-1996.

9. Woo PC, Lau SK, Wong BH, Tsoi HW, Fung AM, Chan KH, Tam VK, Peiris JS, Yuen KY: Detection of specific antibodies to SARS coronavirus nucleocapsid protein for serodiagnosis of SARS coronavirus pneumonia. JClin Microbiol 2004, 42:2306-2309.

10. Yu F, Le MQ, Inoue S, Thai HT, Hasebe F, Del Carmen Parquet M, Morita K: Evaluation of inapparent nosocomial severe acute respiratory syndrome coronavirus infection in Vietnam by use of highly specific recombinant truncated nucleocapsid protein-based enzyme-linked immunosorbent assay. Clin Diagn Lab Immunol 2005, I 2(7):848-54.

II. Lei Shi, Qipeng Zhang, Wei Rui, Ming Lu: Structure and function Analysis of SARS-CoV spike protein. [http://cmbi.bimu.edu.cn/ cmbidata/sars/sars secstructure/spike.htm]

12. Tripp RA, Haynes LM, Moore D, Anderson B, Tamin A, Harcourt BH, Jones LP, Yilla M, Babcock GJ, Greenough T, Ambrosino DM, Alvarez
R, Callaway J, Cavitt S, Kamrud K, Alterson H, Smith J, Harcourt JL, Miao C, Razdan R, Comer JA, Rollin PE, Ksiazek TG, Sanchez A, Rota PA, Bellini WJ, Anderson LJ: Monoclonal antibodies to SARSassociated coronavirus (SARS-CoV): Identification of neutralizing and antibodies reactive to $S, N, M$ and $E$ viral proteins. J Virol Methods 2005, I 28(I-2):2I-28.

13. Liu SJ, Leng CH, Lien SP, Chi HY, Huang CY, Lin CL, Lian WC, Chen CJ, Hsieh SL, Chong P: Immunological characterizations of the nucleocapsid protein based SARS vaccine candidates. Vaccine 2006, 24:3100-3108

14. Peng H, Yang LT, Wang LY, Li J, Huang J, Lu ZQ, Koup RA, Bailer RT, Wu CY: Long-lived memory $T$ lymphocyte responses against SARS coronavirus nucleocapsid protein in SARS-recovered patients. Virology 2006, $351: 466-475$.

15. Zhi Y, Kobinger GP, Jordan H, Suchma K, Weiss SR, Shen H, Schumer G, Gao G, Boyer JL, Crystal RG, Wilson JM: Identification of murine CD8 T cell epitopes in codon-optimized SARS-associated coronavirus spike protein. Virology 2005, 335:34-45.

16. Sestak K, Meister RK, Hayes JR, Kim L, Lewis PA, Myers G, Saif LG: Active immunity and T-cell populations in pigs intraperitoneally inoculated with baculovirus-expressed transmissible gastroenteritis virus structural proteins. Vet Immunol Immunopathol 1999, 70:203-221.

17. Chen WJ, Niu DS, Zhang XY, Chen ML, Cui H, Wei WJ, Wen BH, Chen XR: Recombinant 56-Kilodalton Major Outer Membrane Protein Antigen of Orientia tsutsugamushi Shanxi and Its Antigenicity. Infection and Immunity 2003, 8:4772-4779.

18. Towbin H, Staehelin T, Gordon J: Electrophoretic transfer of proteins from polyacrylamide gels to nitrocellulose sheets: procedure and some applications. Proc Natl Acad Sci USA 1979, 76:4350-4354.

19. Jin DY, Li MF: Molecular Cloning: A Laboratory Manual. 2nd edition. Press of science, Beijing; 1992.

20. Du P: Medical experimental virology. Shanghai Association of Microbiology, Shanghai, China; 1982:21I-212.

21. Andreoni M, Faircloth M, Vugler L, Britt W]: A rapid microneutralization assay for the measurement of neutralizing antibody reactive with human cytomegalovirus. J Virol Methods 1989, 23:157-167.

22. Reed $\mathrm{L}$, Muench $\mathrm{H}$ : A simple method of estimating fifty percent endpoints. Am J Hyg 1938, 27:493-497.

23. Shuhan Sun: Nuclear vaccine. Shanghai: Press of the Second Military Medicine University; 2000:I I 4.

24. Chen WJ, Xu ZY, Mu JS, He B, Yang L, Lin L, Meng SF, Mu F, Gan HX, Huang SY, Wen J, Fang JQ, Wang J: Real-Time Quantitative Fluorescent Reverse Transcriptase-PCR for Detection of Severe Acute Respiratory Syndrome-Associated Coronavirus RNA. Molecular Diagnosis 2004, 8(4):23I-235.

25. Sun ZF, Meng XJ: Antigenic Cross-Reactivity between the Nucleocapsid Protein of Severe Acute Respiratory Syndrome (SARS) Coronavirus and Polyclonal Antisera of Antigenic Group I Animal Coronaviruses: Implication for SARS Diagnosis. Journal of Clinical Microbiology 2004, 42(5):235I-2352.

26. Ksiazek TG, Erdman D, Goldsmith CS, Zaki SR, Peret T, Emery S, Tong S, Urbani C, Comer JA, Lim W, Rollin PE, Dowell SF, Ling AE, Humphrey CD, Shieh W], Guarner J, Paddock CD, Rota P, Fields B, DeRisi J, Yang JY, Cox N, Hughes JM, LeDuc JW, Bellini WJ, Anderson LJ, SARS Working Group: A Novel Coronavirus Associated with Severe Acute Respiratory Syndrome. The New England Journal of Medicine 2003, 348(20): 1953-1966.

27. He Q, Chong KH, Chng HH, Leung B, Ling AE, Wei T, Chan SW, Ooi $\mathrm{EE}, \mathrm{Kwang} \mathrm{J}$ : Development of a Western blot assay for detection of antibodies against coronavirus causing severe acute respiratory syndrome. Clin Diagn Lab Immunol 2004, I I:4 I7-422.

28. Woo PC, Lau SK, Wong BH, Tsoi HW, Fung AM, Kao RY, Chan KH, Peiris JS, Yuen KY: Differential Sensitivities of Severe Acute Respiratory Syndrome (SARS) Coronavirus Spike Polypeptide Enzyme-Linked Immunosorbent Assay (ELISA) and SARS Coronavirus Nucleocapsid Protein ELISA for Serodiagnosis of SARS Coronavirus Pneumonia. J Clin Microbiol 2005, 43(7):3054-3058

29. Wu HS, Hsieh YC, Su IJ, Lin TH, Chiu SC, Hsu YF, Lin JH, Wang MC, Chen JY, Hsiao PW, Chang GD, Wang AH, Ting HW, Chou CM, Huang C): Early detection of antibodies against various structural proteins of the SARS-associated coronavirus in SARS patients. J Biomed Sci 2004, I I ( I): I I 7 - I 26. 
30. Gallagher TM, Buchmeier MJ: Coronavirus spike proteins in viral entry and pathogenesis. Virology 200I, 279(2):37I-374.

31. Hideyuki Kubo, Yasuko K: Yamada and Fumihiro Taguchi. Localization of Neutralizing Epitopes and the ReceptorBinding Site within the Amino-Terminal 330 Amino Acids of the Murine Coronavirus Spike Protein. Journal of Virology 1994, 68(9):5403-5410

32. Yang ZY, Kong WP, Huang Y, Roberts A, Murphy BR, Subbarao K, Nabel G]: A DNA vaccine induces SARS coronavirus neutralization and protective immunity in mice. Nature 2004, 428:56I-564.

33. Park S, Sestak K, Hodgins DC, Shoup DI, Ward LA, Jackwood DJ, Saif LJ: Immune response of sows vaccinated with attenuated transmissible gastroenteritis virus (TGEV) and recombinant TGEV spike protein vaccines and protection of their suckling pigs against virulent TGEV challenge exposure. Am J Vet Res 1998, 59(8): 1002-1008.

Publish with Bio Med Central and every scientist can read your work free of charge

"BioMed Central will be the most significant development for disseminating the results of biomedical research in our lifetime. "

Sir Paul Nurse, Cancer Research UK

Your research papers will be:

- available free of charge to the entire biomedical community

- peer reviewed and published immediately upon acceptance

- cited in PubMed and archived on PubMed Central

- yours - you keep the copyright 